\title{
PENGEMBANGAN MEDIA EVALUASI PEMBELAJARAN PELATIK (PETUALANGAN LABIRIN TEMATIK) PADA TEMA 6 SUBTEMA 1 TENTANG CITA-CITAKU KELAS IV SD
}

\author{
Bagus Ginanjar \\ Pendidikan Guru Sekolah Dasar, Fakultas Ilmu Pendidikan, Universitas Muhammadiyah Jakarta. \\ Jl. KH. Ahmad Dahlan Cirendeu, Ciputat Tangerang Selatan - 15419 \\ Email: bagusginanjar91@gmail.com \\ Apri Utami Parta Santi \\ Pendidikan Guru Sekolah Dasar, Fakultas Ilmu Pendidikan, Universitas Muhammadiyah Jakarta. \\ Jl. KH. Ahmad Dahlan Cirendeu, Ciputat Tangerang Selatan - 15419 \\ Email: tetivianita@gmail.com
}

\begin{abstract}
This research is motivated by the difficulty of students in working on thematic questions and the lack of proper evaluation media for thematic learning. The goal is to develop media for evaluating learning in the thematic learning theme 6 sub themes 1 on my ideals and knowing the level of student response to the media developed. The type of research used is Research and Development (R\&D). The results of the study obtained an assessment rating of the material validated reached $82 \%$ with the predicate "Good / Eligible", the media validated reached $92 \%$ with the predicate "Very Good / Eligible", the language validated reached $82 \%$ with the predicate "Good / Eligible". The media have been declared valid with the statement "No Revision". As for the results of student responses in the small group reaching a percentage score of $99.28 \%$ assessment was included in the group of "very good" or "very decent". In the large group test reaching a percentage score of $97.76 \%$ was included in the group of "very good" or "very possible".
\end{abstract}

Keywords:

Learning Evaluation Media, Pelatik, Thematic Learning

\begin{abstract}
Abstrak
Penelitian ini dilatarbelakangi oleh adanya kesulitan siswa dalam mengerjakan soal tematik dan kurangnya media evaluasi yang sesuai untuk pembelajaran tematik. Tujuannya untuk mengembangkan media evaluasi pembelajaran pelatik pada pembelajaran tematik tema 6 subtema 1 tentang cita-citaku dan mengetahui tingkat respon siswa terhadap media yang dikembangkan. Jenis penelitian yang digunakan adalah Research and Development (R\&D). Hasil dari penelitian diperoleh penilaian penilaian dari validator materi mencapai $82 \%$ dengan predikat "Baik/Layak", validator media mencapai 92\% dengan predikat "Sangat Baik/Layak", validator bahasa mencapai $82 \%$ dengan predikat "Baik/Layak". Media telah dinyatakan valid dengan keterangan "Tanpa Revisi". Sementara untuk hasil dari respon siswa pada kelompok kecil mencapai presentase skor penilaian sebesar 99,28\% sudah termasuk dalam kategori "sangat baik" atau "sangat layak". Pada uji kelompok besar mencapai presentase skor penilaian sebesar 97,76\% sudah termasuk dalam kategori "sangat baik" atau "sangat layak".
\end{abstract}

Kata Kunci:

Media Evaluasi Pembelajaran, Pelatik, Pembelajaran Tematik

\section{A. PENDAHULUAN}

Kurikulum merupakan sebuah program pendidikan yang diberikan oleh suatu lembaga penyelenggara pendidikan. Kurikulum itu sendiri terdapat rancangan yang diperuntukkan untuk tujuan dari sistem pendidikan yang dilaksanakan.

Masih berlakunya kurikulum 2013 pada tahun 2018/2019 dimana masih banyak permasalahan yang kita temukan pada kurikulum. Menurut Otang dan Deddy (2017: 390) perbedaan kurikulum 2013 dengan kurikulum sebelumnya terlihat pada banyak permasalahan yang menjadi hambatan untuk hasil belajar, dilihat dalam media yang digunakan serta penilaian atau evaluasi yang digunakan jauh lebih sulit dibandingkan dengan kurikulum terdahulu. Kurang efektifnya metode pada penyampaian materi bahkan materi yang ingin diajarkan tidak sesuai.

Menurut pandangan peneliti setelah melakukan observasi di SDN 02 Pondok Betung kurikulum yang diterapkan pada kelas IV yaitu kurikulum 2013 atau tematik dimana tematik merupakan penggabungan beberapa mata pelajaran menjadi satu tema sehingga setelah peneliti melakukan observasi peneliti menemukan permasalahan bahwa masih banyak guru yang tidak menggunakan media evaluasi pembelajaran untuk diaplikasikan pada kurikulum 2013 
sehingga murid hanya terpaku pada buku saja. Media evaluasi pembelajaran akan lebih kreatif jika digabungkan dengan permainan. Permainan yang menyenangkan yaitu permainan yang bisa dimainkan didalam dan diluar kelas.

Permainan edukatif adalah permainan yang mengasah pengetahuan. Permainan bertemakan petualangan adalah salah satu permainan yang menarik di mana tujuan dari permainan itu adalah mencapai titik puncak kemenangan. Permainan petualangan tematik adalah salah satunya. Permainan petualangan tematik merupakan permainan papan yang menggunakan dadu, dimana terdapat kotak-kotak dan labirin arah serta kartu pertanyaan tematik sesuai tema, dan terdapat beberapa jebakan permainan.

Berdasarkan uraian di atas maka peneliti menyusun sebuah penelitian dengan judul "Pengembangan Media evaluasi Pembelajaran Pelatik (petualangan tematik) pada Tema 6 sub tema 1 kelas 4 SD".

\section{Belajar}

Sesuatu yang kompleks terjadi pada semua orang dalam perkembangan hidupnya, sejak dia dilahirkan hingga kematiannya adalah belajar. Perubahan tingkah laku adalah pertanda bahwa seseorang telah belajar dalam dirinya. Perubahan tingkah laku tersebut menyangkut baik perubahan yang bersifat pengetahuan, keterampilan, maupun yang menyangkut nilai dan sikap. (Sadiman, 2010: 2)

\section{Media Pembelajaran dan Pendidikan}

Kata media berasal dari bahasa latin medius yaitu secara harfiah berarti 'tengah', 'perantara' atau 'pengantar'. Gerlach \& Ely (1971) mengatakan bahwa media apabila dipahami secara garis besar adalah manusia, materi, atau kejadian yang membangun kondisi yang membuat siswa mampu memperoleh pengetahuan, keterampilan, atau sikap. Dalam pengertian ini guru, buku teks, dan lingkungan sekolah merupakan media (Arsyad, 2013: 3).

\section{Evaluasi Pembelajaran}

Pengertian evaluasi secara umum dapat diartikan sebagai proses sistematis untuk menentukan nilai sesuatu (ketentuan, kegiatan, keputusan, unjuk-kerja, proses, orang, objek dan yang lainnya) berdasarkan kriteria tertentu melalui penilaian dalam Muhirah (2017: 258)

\section{Bermain}

Bermain adalah suatu kegiatan yang dilakukan dengan atau tanpa menggunakan alat, yang menghasilkan pengertian dan memberikan informasi, memberikan kesenangan maupun mengembangkan imajinasi anak (Triharso, 2013:

1)

\section{Pembelajaran Tematik \\ 1. Pengertian Tematik}

Pada era ini tematik masih digunakan pembelajaran terpadu tematik menurut Kurniawan (2014: 95) (webbed) model terjala merupakan model yang menekankan penyatuan beberapa materi yang dirangkai menjadi satu tema.

\section{Landasan Filosofis Pembelajaran Tematik}

Landasan Filosofis dalam pembelajaran tematik sangat dipengaruhi oleh tiga aliran filsafat menurut Bahar dan Kusumawardani (2017: 93) yaitu progresivisme, konstruktivisme dan humanisme

a. Aliran progresivisme pada proses pembelajaran perlu ditekankan pada pembentukan kreatifitas, pemberian sejumlah kegiatan, suasana yang alamiah, dan memperhatikan pengalaman siswa.

b. Aliran Konstruktivisme yang melihat pengalaman langsung siswa sebagai kunci dalam pembelajaran. Prinsip aliran ini yaitu kurikulum ditekankan pada partisipasi siswa pada proses belajar bukan hasil akhir dalam pembelajaran, pusat dalam proses pembelajaran adalah siswa, guru adalah fasilitator untuk membantu siswa belajar.

c. Aliran Humanisme yang melihat siswa dari segi keunikan, potensinya dan motivasi yang dimilikinya. Pengakuan adanya siswa yang lambat dan cepat terhadap hal-hal yang unik dari siswa. Pada aliran ini pendidikan adalah keinginan untuk mewujudkan belajar dimana siswa akan terbebas dari kata gagal

Dari ketiga landasan diatas dapat disimpulkan bahwa pembentukan kreatifitas yang dilakukan oleh peserta didik adalah landasan pembelajaran tematik yang dilakukan dalam kegiatan memberi pengetahuan dan bermakna berdasarkan potensi dan pengalaman yang dimiliki peserta didik.

\section{Media Evaluasi Pelatik}

Media evaluasi pembelajaran pelatik pengembangan dari media yang terdapat pada penelitian Chandra Kusuma Dewa yang berjudul "Game Labirin Berbasis Pengolahan Bahasa Alami Untuk Pengenalan Logika Pemrograman 
Sederhana" Hasil dari penelitian ini berupa sebuah game offline pembelajaran logika pemrograman sederhana yang dilengkapi dengan modul pengolah bahasa alami untuk perintah arah dan perintah gerak dalam Bahasa Indonesia.

Metode yang dipakai pada penelitian ini adalah penelitian dan pengembangan (R\&D) dengan model penelitian jenis Borg and Gall.

Penelitian dilakukan di SDN Pondok Betung 02, Pondok Aren, kota tangerang. Penelitian ini dilakukan sejak Agustus 2019-November 2019.

Subjek pada penelitian ini melibatkan 20 peserta didik sekolah dasar. Langkah-langkah pengembangan yang dikembangkan oleh Borg \& Gall dalam penelitian ini dengan pembatasan. Borg \& Gall (dalam Emzir, 2015: 271) menyatakan bahwa dimungkinkan untuk membatasi penelitian dalam skala kecil, termasuk membatasi langkah penelitian. Penerapan langkah langkah pengembangannya disesuaikan dengan kebutuhan peneliti. Langkah-langkah tersebut antara lain:

\section{Tahap Pengumpulan Data}

Penelitian ini diharapkan memperoleh beberapa aspek dengan analisis kebutuhan dalam pengumpulan data dengan yaitu:

a. Analisis kurikulum, yaitu analisis kurikulum dengan bertanya kepada guru kelas IV di SD mengenai kurikulum yang digunakan. Setelah mengetahui kurikulum yang digunakan maka peneliti dapat mengetahui standar kompetensi yang digunakan dalam tema 6 subtema 1 tentang cita-citaku.

b. Analisis media pembelajaran yang digunakan bertujuan untuk menentukan jenis media pembelajaran yang tepat untuk dikembangkan.

c. Analisis materi, dilakukan dengan cara mengidentifikasi tema 6 subtema 1 tentang cita-citaku pada Rencana Pelaksanaan Pembelajaran (RPP) pada kurikulum yang digunakan di SDN Pondok Betung 02 Tangerang Selatan. Penelitian tersebut kemudian akan dicantumkan pada media pembelajaran.

\section{Tahap Perencanaan}

Merancang konsep diatas kertas dengan membuat gambaran media yang akan dibuat secara garis besar yang akan dilihat secara garis besar. Penetapan kompetensi dasar dengan memperhatikan hasil analisis kurikulum yang telah dilakukan sebelumnya. Mendesain media dan materi dengan menggunakan aplikasi untuk mengedit desain atau gambar.

\section{Tahap Pengembangan}

Pengembangan berisi kegiatan memproduksi rancangan produk yaitu kegiatan:

\section{a. Pemikiran konsep}

Langkah awal membuat media pembelajaran, pada tahap ini dilakukan awal dari kegiatan yaitu menemukan ide/gagasan mengenai media yang akan dikembangkan yaitu membuat konsep permainan berdasarkan analisis kebutuhan.

b. Persiapan bahan

Peneliti melakukan persiapan bahan-bahan yang akan digunakan untuk pembuatan media evaluasi seperti materi, pembuatan tampilan gambar, dan kartu soal.

\section{Tahap Validasi}

Tahapan ini peneliti melakukan uji validasi yang dilakukan oleh 4 validator, 1 validator media, 2 validator materi, dan 1 validator Bahasa.

\section{Tahap Revisi Utama}

Pada tahap kelima yaitu revisi tahap pertama yang merupakan kegiatan merevisi media yang dilakukan setelah media divalidasi oleh para validator dan sebelum diuji ke kelompok kecil.

\section{Uji Coba Kelompok Kecil}

Untuk kelompok kecil yang dilakukan dikelas dengan jumlah 4 responden atau 4 siswa yang akan memainkan media evaluasi pembelajaran ini serta menilai media yang telah diuji coba dengan memberi saran atau perbaikan terhadap media dengan menyebarkan angket terhadap siswa maupun guru kelas, bertujuan untuk mengetahui kelayakan media pembelajaran sesuai dengan harapan.

\section{Revisi tahap kedua}

Revisi media, materi, maupun bahasa peneliti akan melakukan perbaikan sesuai dengan saran yang diberikan responden sebelum dilakukan uji coba kelompok besar.

\section{Uji Kelompok Besar}

Responden yang digunakan berjumlah 8 orang dengan 4 kelompok masing-masing 2 orang tiap kelompok dimana kelas yang digunakan berbeda dengan kelas di uji coba tahap pertama atau uji coba kelompok kecil. Peneliti akan menyebarkan angket terhadap siswa maupun guru kelas, bertujuan untuk mengetahui kelayakan media pembelajaran sesuai dengan harapan.

\section{Revisi Tahap Akhir}


Responden yang digunakan berjumlah 8 orang dengan 4 kelompok masing-masing 2 orang tiap kelompok dimana kelas yang digunakan berbeda dengan kelas di uji coba tahap pertama atau uji coba kelompok kecil. Peneliti akan menyebarkan angket terhadap siswa maupun guru kelas, bertujuan untuk mengetahui kelayakan media pembelajaran sesuai dengan harapan.

\section{Teknik Analisis Data}

Instrumen penilaian ahli dan angket dilakukan untuk mengetahui kualitas produk. Tahapantahapan yang akan dilakukan adalah sebagai berikut (Saidah dan Nugroho 2015: 68-69):

a. Mengubah penilaian kualitatif menjadi kuantitatif dengan ketentuan mengacu kepada skala Likert (Sugiyono 2009: 93) dengan modifikasi.

Tabel 1. Ketentuan Pemberian Skor

\begin{tabular}{|l|c|}
\hline \multicolumn{1}{|c|}{ Kategori } & Skor \\
\hline Sangat Baik & 5 \\
\hline Baik & 4 \\
\hline Cukup & 3 \\
\hline Kurang & 2 \\
\hline Sangat Kurang & 1 \\
\hline
\end{tabular}

b. Menghitung rata-rata skor tiap aspek dengan rumus:

$$
X=\frac{\sum x}{N}
$$

Keterangan: $X=$ Skor rata - rata

$$
\begin{aligned}
& \sum \quad x=\text { Jumlah Skor } \\
& N=\text { Jumlah Indikator }
\end{aligned}
$$

c. Mengubah skor tiap aspek atau indikator menjadi sebuah nilai kualitatif yang menggunakan rumus konvensi skala lima menurut Widyoko (dalam Saidah dan Nugroho 2015: 69) sebagai berikut:

Tabel 2. Rumus Konvensi Rata - rata Skor pada

\begin{tabular}{|c|c|c|}
\hline 5 & $X \overline{>} X \bar{i}+1,8 S B i$ & $\begin{array}{c}\text { Sangat } \\
\text { Baik }\end{array}$ \\
\hline 4 & $\begin{array}{c}X i+0,6 S B i \overline{<} \\
X \leq X i+1,8 S B i\end{array}$ & Baik \\
\hline 3 & $\begin{array}{c}X i-0,6 S B i< \\
X \leq X i+0,6 S B i\end{array}$ & Cukup \\
\hline 2 & $\begin{array}{c}X i-1,8 S B i< \\
X \leq X i-0,6 S B i\end{array}$ & Kurang \\
\hline 1 & $\bar{X} \leq X \bar{i}-1,8 S B i$ & $\begin{array}{l}\text { Sangat } \\
\text { Kurang }\end{array}$ \\
\hline
\end{tabular}
Skala Lima

\begin{tabular}{|c|c|c|}
\hline Skor & Rumus & Kategori \\
\hline
\end{tabular}

Keterangan:

Skor maksimal $=5$

Skor minimal $=1$

Skor maks ideal $=$ Jumlah indikator $\mathrm{x}$ skor maksimal

Skor min ideal $=$ Jumlah indikator $\mathrm{x}$ skor minimal $X^{-} \quad=$ Skor yang diperoleh

$X i^{-} \quad=\frac{1}{2}$ (skor maks ideal + skor min ideal)

SBi $($ Simpangan Baku Ideal $)=\frac{1}{6}($ skor maks ideal skor min ideal)

d. Data yang diperoleh dianalisis menggunakan analisis deskriptif kuantitatif yang dipraktikan dalam distribusi skor dan terhadap persentase yang menggunakan kategori skala penilaian yang telah ditentukan menurut Arikunto (dalam Saidah dan Nugroho 2015: 69).

$$
\begin{aligned}
& \text { Persentase kelayakan tiap aspek/indikator } \% \\
& =\frac{\sum \quad \text { rerata skor yang diperoleh }}{\sum \text { Skor Ideal }} \times 100 \%
\end{aligned}
$$

Tabel 3. Penilaian Kevalidan

\begin{tabular}{|c|c|}
\hline $\begin{array}{c}\text { Persentase } \\
\text { Penilaian }\end{array}$ & Klasifikasi \\
\hline $81 \%-100 \%$ & Sangat Valid \\
\hline $61 \%-80 \%$ & Valid \\
\hline $41 \%-60 \%$ & Cukup \\
\hline
\end{tabular}




\begin{tabular}{|c|c|}
\hline $21 \%-40 \%$ & Kurang Valid \\
\hline $0 \%-20 \%$ & Tidak Valid \\
\hline
\end{tabular}

\section{B. HASIL DAN PEMBAHASAN}

Hasil pengembangan dan penelitian yang dilakukan peneliti sejak awal yaitu:

\section{Tahap Pengumpulan Data \\ a. Analisis Kebutuhan}

Peneliti melakukan pengamatan di sekolah mengetahui bahwa, kesulitan peserta didik dalam pembelajaran tematik adalah mereka masih kesulitan dalam memahami pembelajaran tematik khususnya pada tema 6 subtema 1 tentang citacitaku dikarenakan media evaluasi yang digunakan hanya diperuntukan untuk satu mata pelajaran. Media evaluasi pembelajaran juga kurang menarik yaitu hanya dengan menggunakan buku yang disediakan pemerintah saja.

\section{b. Analisis Kurikulum}

Pada sekolah ini menerapkan kurikulum k13.

\section{c. Analisis Hasil Belajar Siswa}

Pada tahap ini informasi Hasil belajar siswa kelas IV cukup baik dengan memanfaatkan evaluasi menggunakan lembar evaluasi. Nilai ratarata ulangan tematik pada pembelajaran yaitu 7-10 tetapi masih terdapat siswa yang nilainya dibawah KKM. Siswa masih mendapat kesulitan mempelajari pembelajaran tematik terlebih dalam pembelajaran matematika.

\section{Tahap Perencanaan}

Tahap kedua adalah tahap perencanaan yang akan dikembangkan. Media evaluasi pembelajaran yang dibuat dengan berdasarkan perencanaan sebagai berikut:

a. Perencanaan desain media

1) Bentuk Media Pelatik

Media pelatik dibuat dengan bahan yang mudah dibawa seperti kertas yang tahan lama dan mudah disimpan agar media mampu digunakan kapanpun dan dimanapun.

2) Desain media evaluasi pembelajaran Pelatik

Media evaluasi PELATIK akan dikembangkan dengan bertemakan petualangan dimana dasar dari permainan ini adalah bentuk labirin dengan kotakkotak didalamnya yang dikaitkan dengan pembelajaran tematik didalamnya.

\section{Tahap Pengembangan}

Langkah selanjutnya adalah pengembangan media evaluasi pembelajaran yaitu:

1) Menentukan komponen Media

a. Pemilihan Huruf

Pemilihan huruf yang digunakan bervariasi agar lebih menarik, seperti tulisan pelatik di papan menggunakan jenis tulisan abstract labyrinth dan diganti arial setelah direvisi, isi kartu dan buku panduan juga menggunakan arial.

b. Penggunaan gambar

Gambar yang digunakan yakni mengambil gambar-gambar gratis dari internet yang berlisensikan gratis dari situs freepic dan diedit dengan menggunakan adobe Illustrator.

c. Pemilihan warna

Pemilihan warna sangatlah penting warna dasar dari papan permainan PELATIK adalah warna biru muda agar terkesan menyenangkan. Warna untuk kotak warna pada kotak setop adalah kuning dan merah sama seperti kartu setop/pertanyaan bertanda bahwa harus berhenti dan mengambil kartu soal.

Warna untuk kotak start ada 3 warna yaitu pink, hijau dan ungu, warna ini memiliki arti yaitu pink berarti harus jalan kekiri, hijau berarti harus diam ditempat dan ungu berarti harus jalan kekanan berlaku pada awal permainan di kotak start jika salah menjawab soal tetapi jika salah menjawab soal pada kotak setop maka ikuti arah warna saja.

Warna gelap diberikan oleh kotak dan kartu malas serta boom dimana warna yang diberikan adalah warna abu-abu untuk kotak malas dan kartu malas dan warna hitam untuk kotak boom dan kartu boom dikarenakan didalamnya terdapat hukuman maka kesan yang diberikan adalah warna gelap.

d. Pemilihan teknik dan pembuatan PELATIK

Pembuatan pelatik yaitu dengan menggunakan kertas yang sangat mudah dibawa kemanapun dan kapanpun tetapi tahan lama dan awet yaitu kertas albartos.

2) Desain yang dikembangkan

a) Papan Labirin 
Desain labirin pelatik dibuat kotak-kotak kecil yang terhubung satu sama lain sehingga banyak jalan menuju kotak finish agar siswa dapat berfikir secara kritis jalan tercepat menuju kotak finish. Didalam permainan tersebut terdapat 4 kotak kartu disudut-sudut sisinya yaitu kartu malas, rajin, boom dan stop/pertanyaan.

Dalam labirin juga terdapat kotak-kotak yang bertuliskan stop dengan arah panah, dan boom, dan lambang $\mathrm{R}$ yang berarti rajin dan lambang $\mathrm{M}$ berarti malas. Disekitar kotak setop juga terdapat warna pink, hijau dan ungu sama seperti pada kotak start yang berfungsi sebagai aturan warna jika siswa atau pemain salah menjawab soal. Berikut gambar media pelatik Papan pelatik terbuat dari kertas yang mudah digunakan, dibawa, dan dimainkan kapanpun dan dimanapun dengan kertas albartos berukuran A1 atau 594mm X $841 \mathrm{~mm}$ seperti gambar berikut:

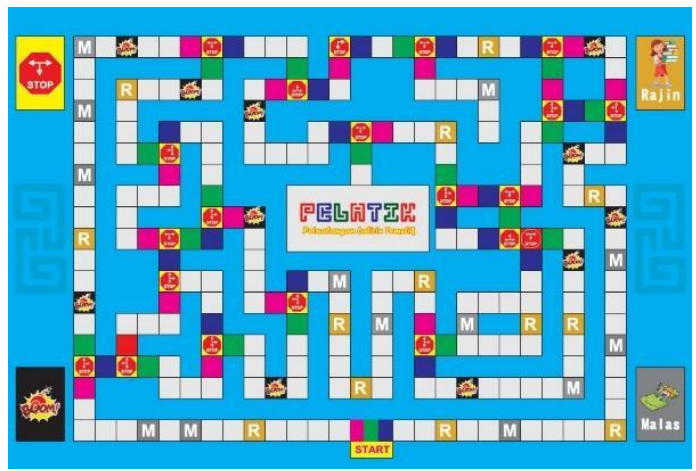

Gambar 1. Papan Media PELATIK

b) Tempat media pelatik

Terdapat tabung gambar untuk menempatkan media PELATIK dengan tinggi berukuran $64 \mathrm{~cm}$ dan diameter $10,5 \mathrm{~cm}$. Berikut gambar tabung media:

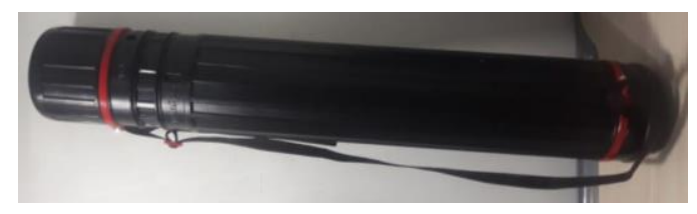

Gambar 2. Tabung Media

c) Kartu Permainan

Kartu rajin yang bergambar anak perempuan sedang membawa buku dan terdapat tulisan rajin. Didalam kartu rajin terdapat kata motivasi dan mendapatkan hadiah berupa maju beberapa langkah kartu ini berwarna orange.

Kartu malas menggambarkan seorang anak yang sedang bermalas-malasan tidur dan mereka mendapat hukuman berupa mundur beberapa langkah kartu ini berwarna abu-abu. Kartu tersebut mengingatkan mereka agar tidak malas dan terus rajin.

Selain itu juga terdapat kartu Boom dan kartu setop (pertanyaan), dimana kartu Boom berlambangkan gambar Bom dengan tulisan Boom. Kartu boom ini bertujuan agar permainan tidak monoton dan membosankan jika terdapat hukuman atau jebakan yang menyenangkan kartu ini berwarna hitam untuk warna dasar. Sedangkan kartu setop atau pertanyaan melambangkan rambu $\mathrm{S}$ dengan tulisan stop.

Pada kartu stop terdapat soal-soal yang disajikan didalam kartu berupa soal tematik guna siswa terlatih dalam mengerjakan soal tematik, kartu ini berwarna kuning untuk warna dasar. Semua kartu tersebut berukuran $6 \mathrm{~cm} \times 9 \mathrm{~cm}$ dengan jenis kertas art carton 310 gram. Berikut gambar kartu setop, boom, rajin dan malas. Berikut gambar kartu dalam permainan PELATIK

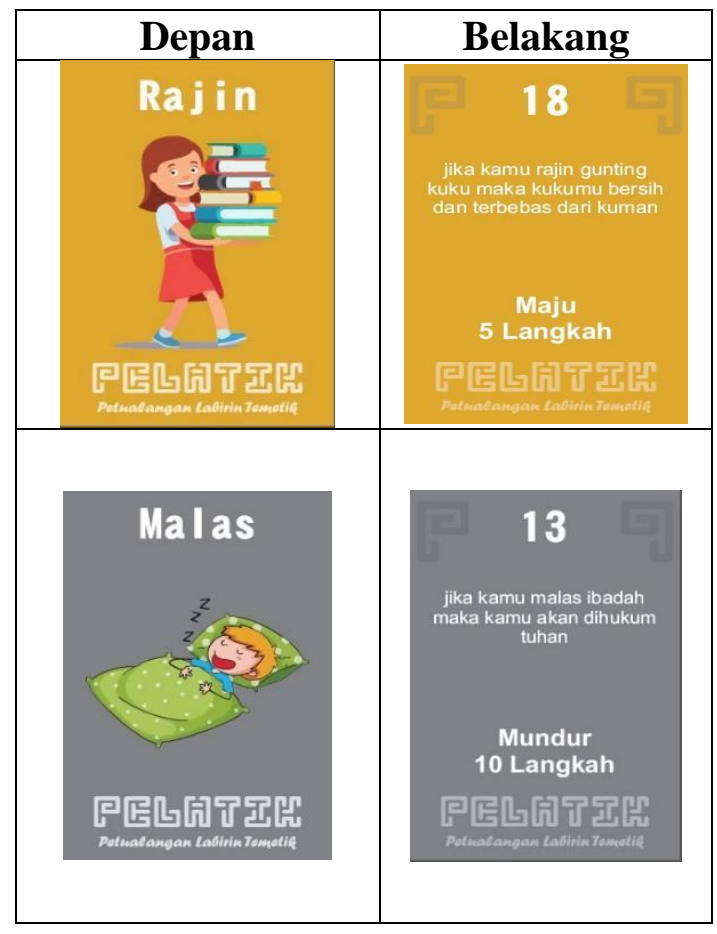




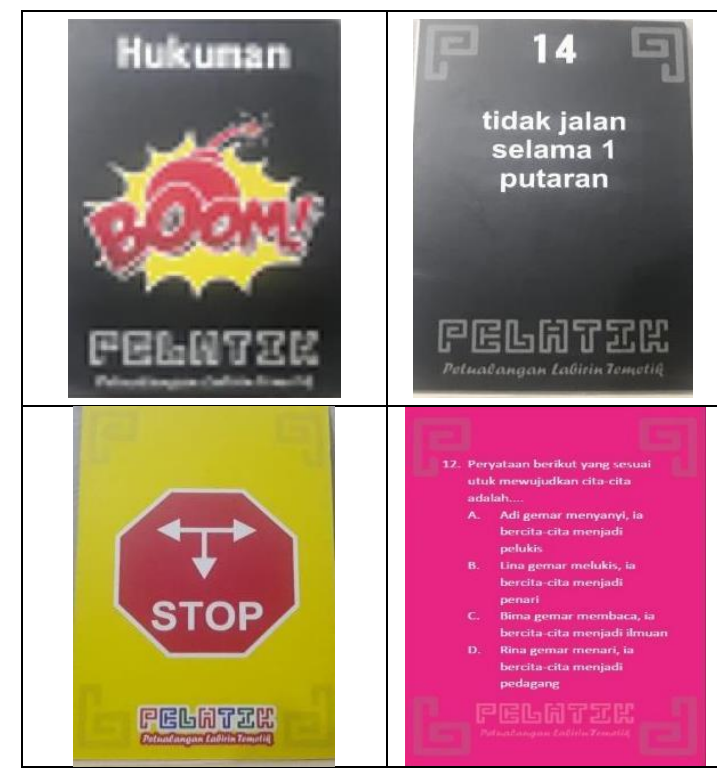

Gambar 3. Kartu Permainan

d) Buku Panduan PELATIK

Buku panduan permainan dibuat di kertas jenis art paper dengan ukuran $22 \mathrm{~cm}$ $\mathrm{x} 16 \mathrm{~cm}$ yang telah diketik dan didesain semenarik mungkin dengan berbentuk booklet. Dalam panduan terdapat cara bermain media pelatik serta peraturanperaturan yang terdapat pada media pembelajaran pelatik, sehingga tidak membuat guru maupun siswa menjadi bingung. Buku panduan seperti gambar dibawah:
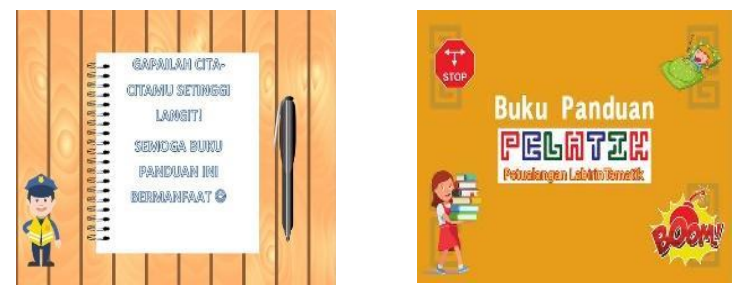

Gambar 4. Cover Depan Dan Belakang Buku Panduan

e) Pion Permainan PELATIK

Pion yang digunakan terbuat dari bahan dasar akrilik yang dibuat dengan teknik pemotongan menjadi sesuai bentuk karakter profesi dan menempelnya menjadi dua lapis yang di bagian dalam terdapat potongan gambar pion.

Karakter pada pion yang digunakan sesuai dengan tema 6 sub tema 1 tentang cita-citaku yaitu:

- Polisi

- Koki
- Dokter

- Pemadam kebakaran

- Serta guru

Seperti gambar dibawah ini

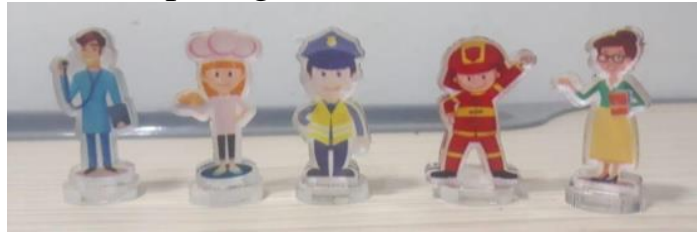

Gambar 5. Pion Permainan PELATIK

\section{Tahap Validasi}

Setelah melewati tahapan pengembangan, peneliti melakukan validasi terhadap validator media, materi dan bahasa

a. Validator Media

Aspek yang dinilai adalah aspek kelayakan media memperoleh skor 87 atau mendapat kriteria sangat baik. Total secara keseluruhan maka mendapat skor 87 atau jika dipersentasekan menjadi $92 \%$ dengan kriteria sangat valid.

b. Validator Materi

Aspek yang dinilai adalah aspek kelayakan isi memperoleh skor 46 atau mendapat kriteria baik. Sedangkan aspek kelayakan penyajian memperoleh skor 24 atau mendapat kriteria baik. total secara keseluruhan maka mendapat skor 70 atau jika dipersentasekan menjadi $82 \%$ dengan kriteria sangat valid.

c. Validator Bahasa

Aspek yang dinilai adalah aspek Penilaian Bahasa memperoleh skor 45 atau mendapat kriteria sangat baik. total secara keseluruhan maka mendapat skor 45 atau jika dipersentasekan menjadi 82\% dengan kriteria sangat valid.

\section{Revisi Tahap Utama/Pertama}

Setelah dilakukan validasi maka dilakukannya revisi tahap utama atau pertama

a. Revisi Validator Materi

Merevisi penambahan karakter pion profesi yang kekinian agar permainan mengikuti zaman dan siswa lebih tertarik untuk memainkannya.Serta menambahkan isi materi puisi.

b. Revisi Validator Media

Merevisi memperbesar tulisan dari kartu soal serta desain kartu dibuat menjadi lebih menarik.

c. Revisi Validator Bahasa

merevisi kata pelatik diubah menjadi lebih jelas, kata stop diubah menjadi setop, kata 
finish dan start menjadi cetak miring dan beberapa kata yang rumpang di buku panduan telah diperbaiki.

Berikut adalah gambar hasil perbaikan revisi validator materi, media, dan bahasa

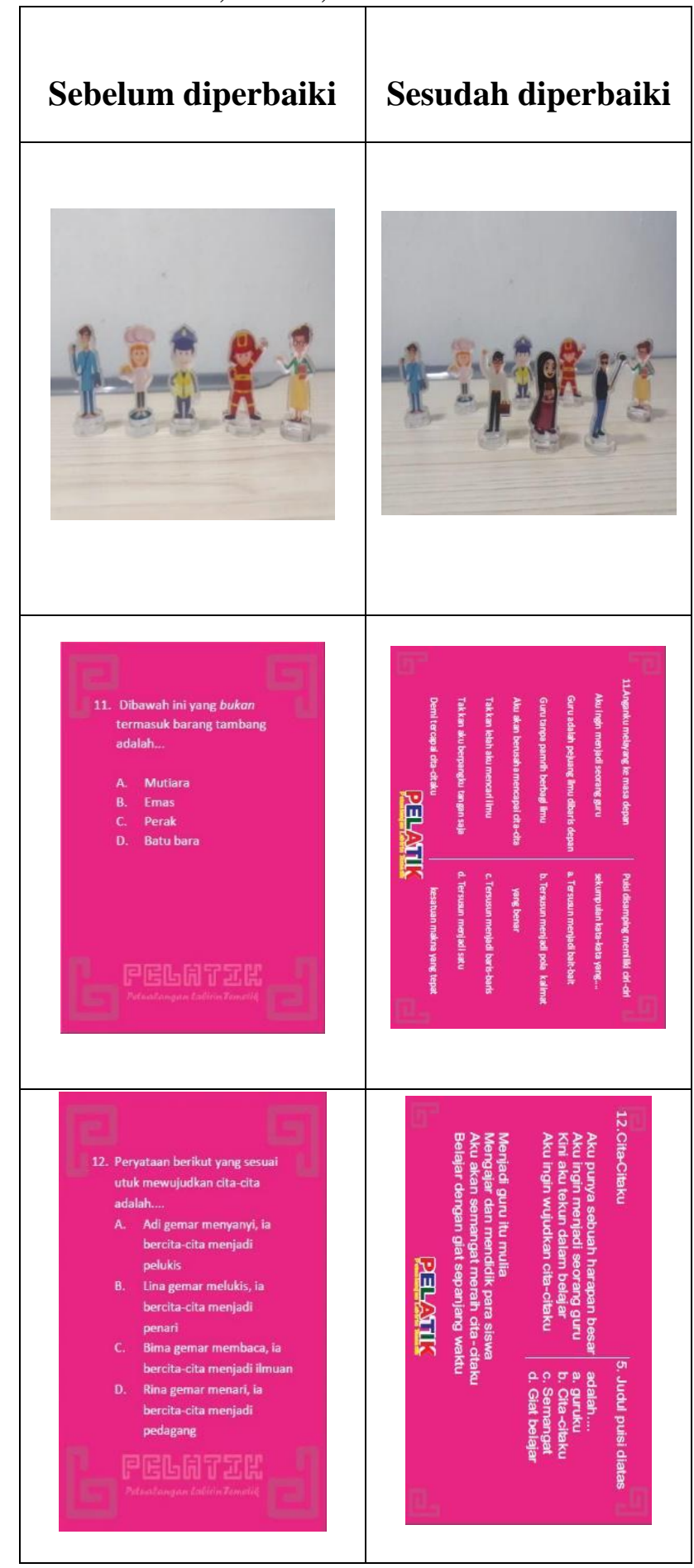

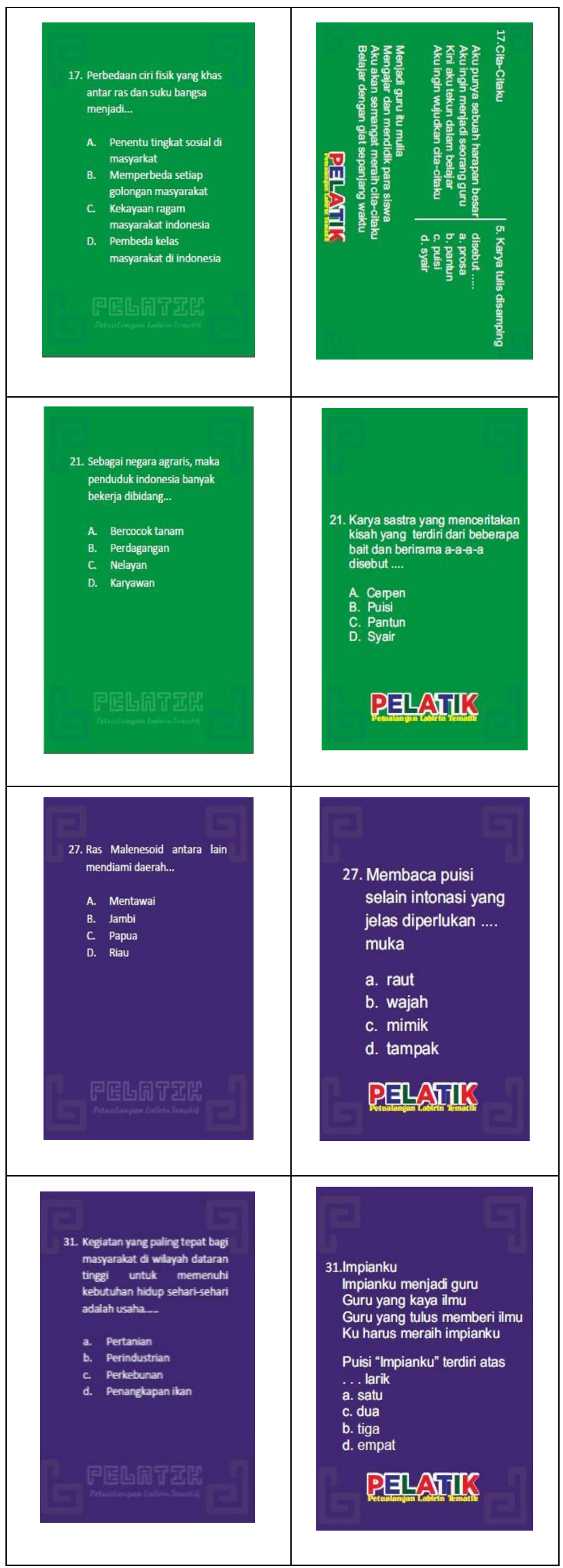

Gambar 6. Revisi Validator materi 


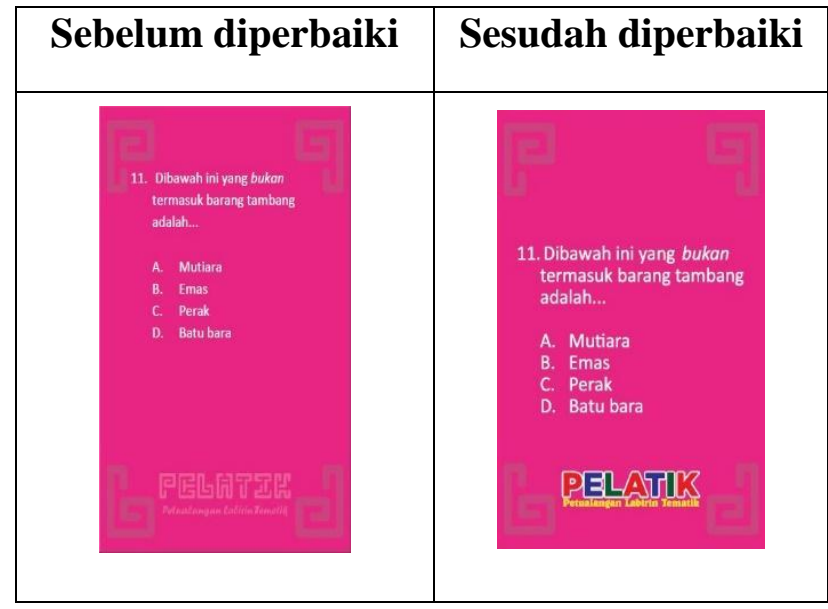

Gambar 5. Pion Permainan PELATIK

\begin{tabular}{|l|l|}
\hline Sebelum diperbaiki & Sesudah diperbaiki \\
\hline STOP & \\
\hline SETOP
\end{tabular}

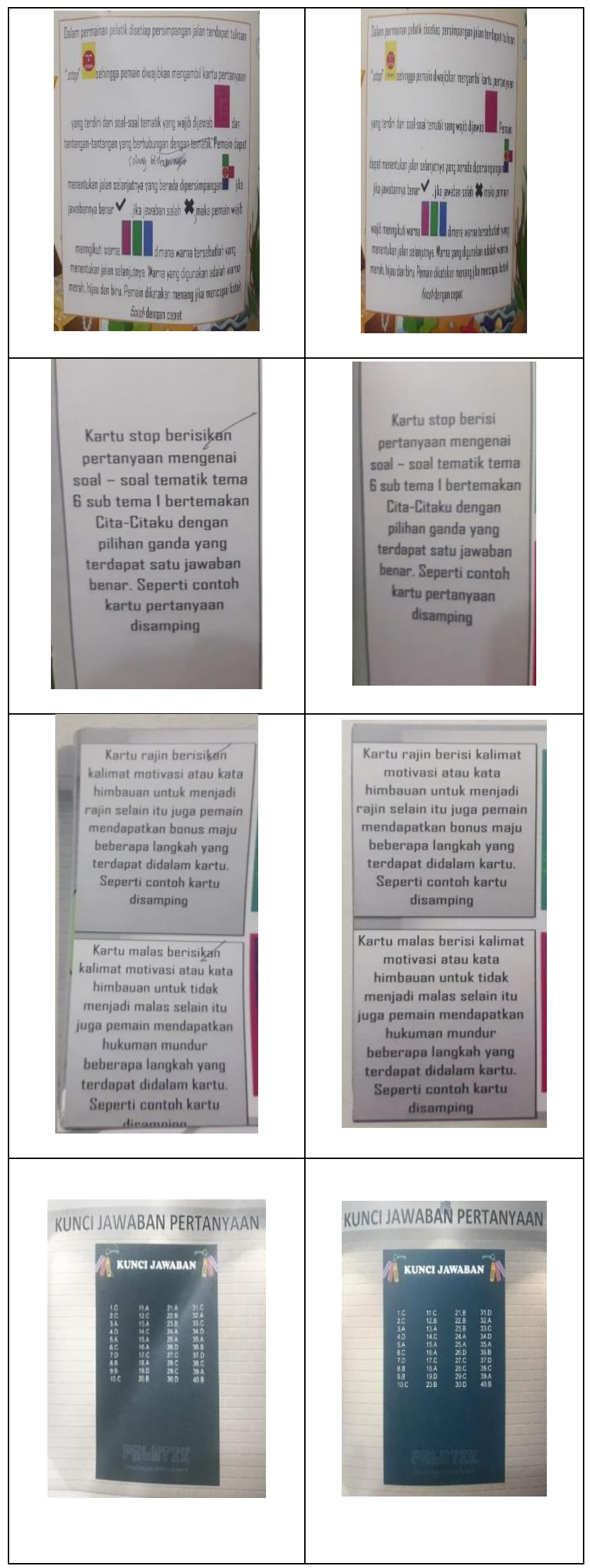




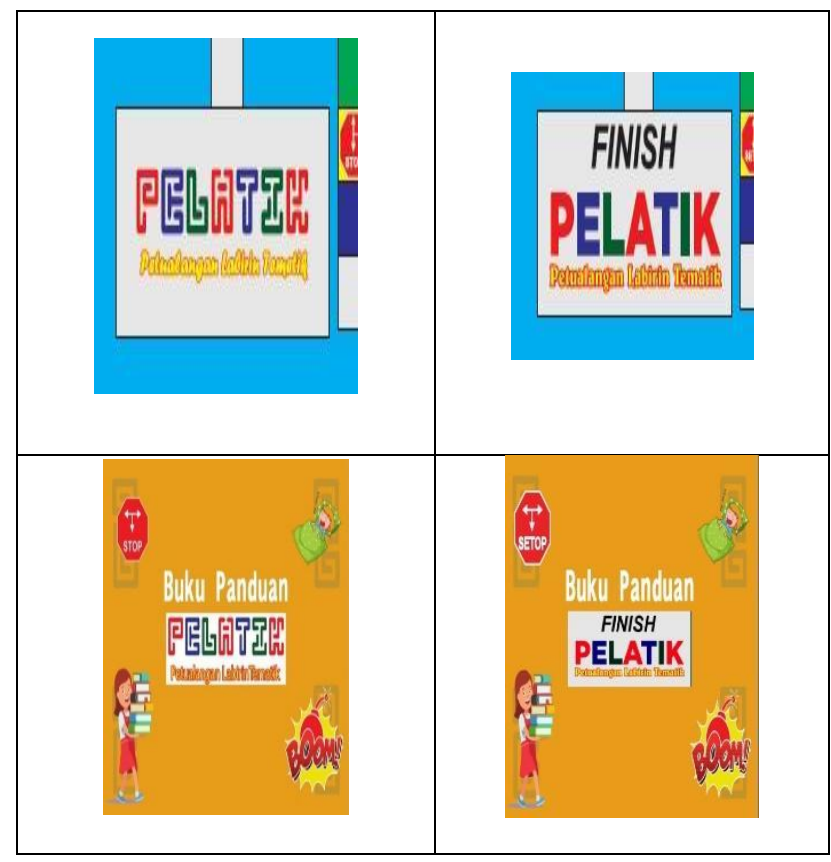

Gambar 7. Revisi Validator Bahasa

\section{Uji Kelompok Kecil}

Setelah melakukan revisi tahap pertama maka dilakukanlah uji kelompok kecil dari aspek kebermanfaatan memperoleh skor 14,67. Kriteria sangat baik dari aspek keterlaksanaan media mendapat skor 30. Kriteria sangat baik dari aspek tampilan media mendapat skor 25 . Kriteria sangat baik dari aspek materi mendapat skor 19,75. Kriteria sangat baik dari aspek bahasa mendapat skor 15. Jika ditotal secara keseluruhan maka mendapat skor 104, 42 atau jika dipersentasekan menjadi 99, 28\% dengan kriteria sangat Layak.

\section{Revisi Tahap Kedua}

Tidak ada yang perlu direvisi pada tahap ini. Adapun komentar dari siswa yang diujicobakan yaitu:

a. R1: "Saya senang bermain pelatik bersama teman-teman. Permainan pelatik gampang untuk dimainkan atau tidak sulit".

b. R2: "aku suka bermain media ini

c. R3: "Saya senang bermain pelatik bersama teman-teman permainan pelatik sangat seru.

d. R4: "permainannya sangat bagus dan mudah dimengerti, belajar menjadi sangat seru dan tidak membosankan dan kita menjadi banyak ilmu pengetahuan.

\section{Uji Kelompok Besar}

Aspek kebermanfaatan memperoleh skor 14,5. Kriteria sangat baik dari aspek keterlaksanaan media mendapat skor 28,87. Kriteria sangat baik dari aspek tampilan media mendapat skor 24,67. Kriteria sangat baik dari aspek materi mendapat skor 20. Kriteria sangat baik dari aspek bahasa mendapat skor 14,61. Jika ditotal secara keseluruhan maka mendapat skor 102,65 atau jika dipersentasekan menjadi 97,76\% dengan kriteria sangat Layak.

\section{Revisi Tahap Akhir}

Tidak ada yang perlu direvisi pada tahap ini. Adapun komentar dari siswa yang diujicobakan yaitu:

a. R1: "aku suka permainannya"

b. R2: "saya senang dengan media ini"

c. R3: "saya senang sekali permainan evaluasi, dan saya tertarik dengan evaluasi dan pelajaran tematik"

d. R4: "memainkan pelatik cukup seru sama seperti belajar, media ini cukup mengasah otak dan tidak membuat saya bosan".

e. R5: "permainan pelatik sangat bagus untuk kelas IV karena permainannya seru dan juga hampir semua pertanyaan sudah dipelajari jadi bagus banget deh".

f. R6: "saya suka dengan latihan ini karena ada yang gampang dan ada yang susah".

g. R7: "saya tidak bosan dengan permainan ini dan saya sudah dengan pelajaran ini".

h. R8: "aku bermain dengan senang".

i. R9: "aku bermain dengan senang"

j. R10: "aku senang bermain permainan ini"

k. R11: "sangat tidak bosan dan seru".

1. R12: "saya bermain senang karena permainannya sangat seru dan menyenangkan".

m. R13: "terimakasih karena sudah membuat buku yang lengkap dengan pengertian yang jelas.

n. R14: "saya senang bermain sekaligus belajar hari ini".

o. R15: "aku senang karena aku dapat belajar dengan baik".

p. R16: "Saya sangat senang bermain media ini".

\section{SIMPULAN}

erdasarkan hasil perhitungan dengan menggunakan skala likert melalui uji validasi yang dilakukan oleh 4 validator. Media pembelajaran Pelatik yang dikembangkan mendapatkan penilaian dari validator materi 
mencapai $82 \%$ dengan predikat "Baik/Layak". validator media mencapai $92 \%$ dengan predikat "Sangat Baik/Layak". validator bahasa mencapai $82 \%$ dengan predikat "Baik/Layak". media telah dinyatakan valid karena $\geq 61 \%$ dengan keterangan "Tanpa Revisi".

Hasil dari siswa yang merespon media pembelajaran pelatik pada uji kelompok kecil mencapai persentase skor penilaian sebesar 99,28\% sudah termasuk dalam kategori "sangat baik" atau "sangat layak". Pada uji kelompok besar mencapai persentase skor penilaian sebesar $97,76 \%$ sudah termasuk dalam kategori "sangat baik" atau "sangat layak", sehingga media ini sesuai untuk siswa kelas 4 pada Tema 6 subtema 1 tentang cita-citaku.

\section{DAFTAR PUSTAKA}

Arsyad, Azhar.2013. Media Pembelajaran-Ed Revisi. Jakarta: Rajawali Pers

Bahar, Herwina dan Siska Kusumawardani.2017. Pembelajaran Tematik di SD sebagai acuan penanaman nilai-nilai karakter. Jakarta: Fakultas Ilmu Pendidikan UMJ

Kurniawan, Deni. 2014. Pembelajaran Terpadu Tematik (Teori, Praktik, dan Penilaian). Bandung: Alfabeta

Kurniawan, otang. 2017. Pengaruh Kurikulum 2013 dalam Meningkatkan Keterampilan, Sikap, Pengetahuan. Jurnal Primary. Vol.6 (2): 389-396

Mahirah. (2017). Evaluasi Belajar Peserta Didik. Jurnal Idaarah, Vol.1 (2): 257-267

Sadiman, dkk. 2010. Media Pendidikan: Pengertian, Pengembangan, dan Pemanfaatannya. Jakarta: PT. Raja Grafindo Persada
Saidah, Nugroho. 2015. Pengembangan Media Pembelajaran Berbentuk Permainan Edukasi Akuntansi Cari Kata (Acak) Menggunakan Adobe Flash Cs5. Jurnal Pendidikan Akuntansi Indonesia, Vol. XIII(1): 65-74

Sugiyono. 2015. Metode Penelitian pendidikan: pendekatan kuantitatif, dan $R \& D$. Bandung: Alfabeta

2015. Metode penelitian \& pengembangan: Research and Development. Bandung: Alfabeta.

Triharso, Agung. 2013. Permainan Kreatif dan Edukatif untuk Anak Usia Dini. Yogyakarta: Andi Offset. 